\title{
“PLACES OF THE HEART": FEMALE REGIONALIST WRITERS IN NINETEENTH-CENTURY U.S. LITERATURE
}

\begin{abstract}
RESUMEN
Este artículo es el segundo de una serie que trata de las relaciones entre las mujeres y el espacio. Mientras que el artículo anterior se concentra en el regionalismo en general, y en su lugar en el desarrollo de la literatura de los Estados Unidos (especialmente durante el siglo XIX), en esta discusión se enfocan con mayor detalle las mujeres escritoras de la ficción regionalista y de "color local" en la última mitad del siglo XIX. De esta manera, se examinan temas transcendentes que conciernen a las tradicionales interrelaciones de género, lugar y literatura, y las formas en que el estilo narrativo, las estrategias y las valoraciones se relacionan con la identidad, particularmente la identidad de género.
\end{abstract}

Kari Meyers Skredsvig

\begin{abstract}
This article is the second in a series of articles which revolve around relationships between women and space. While the previous article concentrates on regionalism in general and its place in the development of U.S. literature (especially in the nineteenth century), in this discussion I focus in greater detail on female writers of regionalist and local color fiction in the last half of the nineteenth century. In so doing, I examine major issues concerning traditional interrelationships of gender, place, and literature, and the ways in which narrative style, strategies, and valuations concern identity, particularly gendered identity.
\end{abstract}

"Regionalism"—-both as a type of literature and as a social reality_-generally seems to occupy a privileged place in the hearts and minds of people in the U.S., perhaps because in spite of the traditional insistence on autonomy and uniqueness at both individual and group levels, we not only strive for but also cherish a sense of belonging. Thus, somewhat ironically, regionalist literature in the U.S. has served multiple, often contradictory functions, from its original heroic attempts to define a new nation, to its post-Civil War functions of simultaneously soothing wounded regional pride while forging a revisionist national identity, to its frequent contemporary purpose of providing a sense of identity in a society which no longer easily or automatically fulfills that need. This diversity also permits and explains the amorphousness of the concept of regionalism itself: "regionalism" has been used in U.S. literary historiography in different instances, whether conscientiously or otherwise, to identify national, regional, community, and local areas, almost always in a geographical sense. I specify the latter, obvious as it may appear, because contemporary literary critics and social scientists are forging intriguing new concepts of place and space which privilege a more symbolic, metaphorical approach to "geography" as it contributes to issues of politics, values, ideologies, economies, social relations, and especially identity. My main interest in the discussion which follows, however, is to examine the significance of "region" and "regionalism" in terms of U.S. women writers of the post-Civil War nineteenth-century period. 
In U.S. literary studies, regionalism refers to both a type of literature and a literary movement. As a type of literature, regionalist writing has remained essentially the same: a kind of writing which not only manifests but is grounded in a specific geographical area in ways which characterize and constitute it. As a literary movement, regionalism is generally perceived as part of the much larger philosophical and literary movement known as realism, which evolved in the aftermath of the Civil War (1861-1865) and dominated the literary scene well into the twentieth century, (although regionalism as a historical movement is generally considered to have ended with the century). Critic Millicent Bell describes regionalism as "the impulse towards local realism" (469) and characterizes it as manifesting "the localizing, specifying effects of the conviction that human events grow out of the soil of a particular time, place, race" (470). We need to keep in mind, however, as Marjorie Pryse has so articulately argued, that regionalism and realism are disputed terms:

\begin{abstract}
[D]espite a century of attempts at critical definition, "realism" itself has remained an elusive concept. We have come to designate certain writers as "realists" more by convention and convenience for anthologists than because they share any coherent set of assumptions about fiction. [.... The very act of designating a particular group of writers "regionalist" seems itself theoretical. "Theorizing" regionalism thus becomes an attempt to specify what critical assumptions lie behind the process of drawing inferences from these texts that have led us to propose that the texts form a coherent tradition (2).
\end{abstract}

One significant manifestation of the above is the use of the term "local color" by some critics, authors, and editors; while some use the term as synonymous with "regionalism", others posit important differences which dictate employment of one term or the other. Judith Fetterley and Marjorie Pryse, for example, assert that "local colorists" tended more toward perspectives using humor and ridicule, while "regionalists" were more empathetic towards their subjects. For present purposes, however, possible distinctions between the two terms are less important than similarities in how they function in examining women writers of the period.

In women regionalists' writing, "region" as a geographical issue is intertwined with larger issues of "women's sphere", in the sense that the local realities which constitute their basic content generally revolve around the daily lives of the female protagonists of their fiction. Those lives are circumscribed not merely by the physical limits of their immediate context, but also by the patriarchal premises underlying their sense of space and place, a social reality which has come to be labelled "women's sphere." At issue here are very fundamental ideological considerations related to classic U.S. dichotomies of universal vs. particular (and its variant: national vs. local), collective vs. individual, and feminine vs. masculine. As poststructuralists - particularly deconstructionists like Jacques Derrida-have made clear, Western societies, like the U.S., tend to be phallogocentric, that is, male-centered and hierarchical in their logic. Feminist critics often appropriate Derrida's concept of the logic of the supplement to substantiate their position that in a patriarchy, the masculine occupies the privileged place of "center", while the feminine is relegated to the subordinated space at the margins. While both are necessary to support the system, feminists concentrate on women's patriarchal status as "other", especially how that status is constructed, perpetuated, and challenged. Nongendered aspects function similarly; what is perceived is universal is privileged over the "merely" local, or in the case of U.S. literature, that posited as "national" is 
perceived as superior to the "simply" local. Without getting into a prolonged discussion of how the so-called "universal" or "national" inevitably attempts to neutralize "difference" in its many facets, suffice it to say that, traditionally, labels such as "regional" and "local" are both employed and perceived by many as somehow restrictive, and therefore, "less" or inferior. "Women's sphere" (or even more problematically, "woman's sphere") likewise designates a place with clear boundaries, with limitations, which is thus perceived by patriarchal eyes as "lacking" or negative. It goes without saying that women's regionalist writing, as a result, although popular in its day, has not been accorded high status in U.S. literary studies, but rather has been passed over in rather perfunctory fashion for texts which are "more important" or "better quality", that is, texts which respond more explicitly to the interests and criteria of dominant patriarchal judgments.

Thus, the term "women's sphere" highlights a debate between two conflicting ideologies: a patriarchal ideology which is concerned with "keeping women in their place", and an opposing, feminist ideology which contests such impositions. Not surprisingly, the responses of women regionalist writers and, somewhat surprisingly, women critics and literary historians, also tend to fall into categories of support and opposition, in the sense that some embrace the concept of separate spheres as enlightening and empowering, while others battle against it as belittling and oppressive. (It is necessary to remind ourselves that just as being of one sex or the other does not automatically determine whether one ascribes to patriarchal ideology or not, neither does being a feminist condition one's response in a single direction.) In , critics Sandra Gilbert and Susan Gubar examine metaphors of female enclosure, including the patriarchal stereotypes of "angel" and "demon" that are used to keep women in "their" place, their sphere. This sphere consists basically of the home, where in a patriarchal world women are supposed to find fulfillment as "angelic" (idealized) wives and mothers, characterized by self-sacrifice, innocence, purity, delicacy, nurturing, and obedience. The "demon", of course, is any woman who refuses to conform to such expectations or who is used in scapegoat fashion by being perceived as problematic in multiple ways. Issues of "women's place", of course, go beyond physical space to encompass definitions of femininity and social roles.

Gilbert and Gubar productively question, in their famous opening sentence, whether "the pen is a metaphorical penis" which might cause any woman author to be condemned simply on the basis of her "daring" to write. In the case of women writers in the late nineteenth century, this is a distinct possibility. According to literary historians such as Frank Mott, Michael Bell and Ann D. Wood, women authors undeniably dominated the publishing market at that time, a fact which provoked Nathaniel Hawthorne into making his infamous derogatory remark about "that damned mob of scribblin' women". They ascribe that situation in part to social conditions which fomented the professionalization of authorship, the concomitant business potential of writing, and the rise of "sentimental" domestic fiction due to the increasingly literate, middle-class female readership, among other factors. At the risk of digressing, it is worthwhile noting that the fact that the authors of the bestsellers of the period - with the notable exception of Harriet Beecher Stowe - are no longer even familiar names to today's students of literature is probably due as much to the fact that they seriously threatened male hegemony in their field as it is to the questioned aesthetic quality of some of their writing (itself a manifestation of patriarchal criteria of what was deemed "good", "valuable", "worthwhile", and even "verisimilar"). Critic Donna M. Campbell asserts, in Resisting 
Regionalism: Gender and Naturalism in American Fiction, 1885-1915, that regionalism's demise and naturalism's rise were significantly gender-related:

\begin{abstract}
The naturalists were heirs to a large and complicated tradition in which men critiqued and resisted women's influence, and partly because of that tradition, female local color fiction acquired a salient power for them. Although it would not be fair to say that the naturalists wrote solely in response to the female local color tradition, they clearly were not quite as indifferent to it as their nonfiction writings might suggest. The very diversity of their efforts bespeaks their eagerness to counteract, to demythologize, and sometimes to destroy what they considered a pernicious influence on the literary scene (174).
\end{abstract}

Clearly, "women's place" was much more than a "simple" domestic issue; it was ideological in far-reaching ways-commercially, psychologically, politically, artistically, and socially.

In responding to such concerns, Marjorie Pryse raises some critical questions. She suggests that any attempt to categorize unavoidably brings up the issue of essence: "How do we attempt to distill the essences of a literary genre or tradition developed and practiced by women writers without reinforcing belief in the existence of essential, even biological, differences between 'men writers' and 'women writers'?" (2). Pryse also asserts that "many regionalist texts tend to contradict the cultural ideology of 'women's sphere' [...by] presenting characters who do not occupy their 'essential' place as nineteenth-century American society defined it [as wives and mothers] for white middle-class women" (2). She differentiates between "women's sphere" and "women's culture", where the former refers to the idea of the home and domestic duties, while the latter "signifies the rhetorical act of creating a space rather than specifying what the space has to look like" (6). Pryse bases her position on the connection between sphere and region, asserting that "regions always exist within, and are subordinated by, some other rule." This is suggested by its etymology, which derives from "the same Latin root, regere, to rule, as the words for rex or realm, those rhetorical and political entities that perform the act of subordination on the region" (7). In examining literary texts in terms of their resistance or acquiescence to patriarchal ideology, Pryse suggests the following significance for those terms: "The concept of 'separate spheres' partitions women off: it regionalizes them. But when women characters create their own regions, when they hang a curtain and designate a particular 'sphere' as one of their own construction, they transform 'woman's sphere' into 'women's culture" (8). Her distinction between the two terms parallels the dichotomy in feminist criticism's responses to women regionalists' writing in the sense previously discussed, of either criticizing or mythifying their literary positions. She goes even further in suggesting that

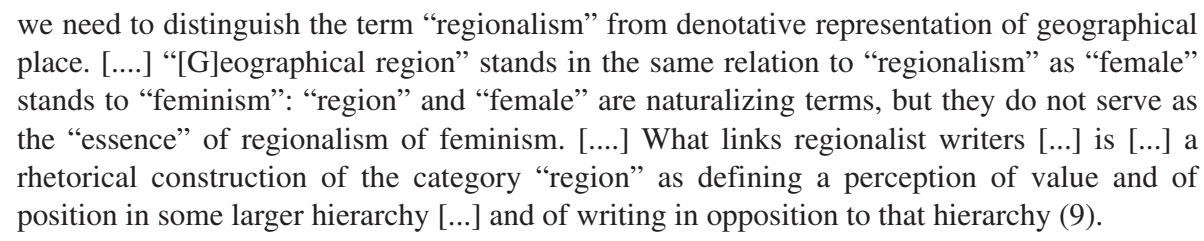

In Pryse's position, "sphere" is clearly a reduction of "region", and both are politically significant. 
Regionalist writing (including "local color") is most often characterized as realistic representation (or even reproduction) of the speech, dress, manners, customs, and idiosyncrasies of a given place. That "place" is traditionally understood as a definite (if not necessarily explicitly defined) geographical location responding to clear space-time coordinates. As Fetterley and Pryse observe, however, "white men did not write the same kinds of regionalist texts that some white women or some members of minority groups did" (xi); in other words, the "reality" perceived and inscribed in the text ineluctably manifests the writer's own position (including gender), no matter what narrative perspective is employed. Point-of-view is a major element in regionalism, especially in terms of tone, narrative distance, and reader response. In examining women regionalist writers, Fetterley and Pryse analyze the connections between the role of the narrator and its effect on the reader and conclude that the narrators' identification with the material of their stories evokes a parallel feeling of empathy on the part of the reader: "Reading becomes a synonym for listening: regional writers create regional characters in order to enlarge the hearts and perspectives of their readers [...]" (xviii). This assertion itself somewhat ironically demonstrates their point, since it (logically) responds to their own agenda of seeking to establish a coherent, cohesive, female regionalist body of texts which fulfills their own needs as feminist critics: “[...] capable of answering our need for tradition, for literary mothers, and for a place of our own in American literary history, $[\ldots .$.$] the effort to create community [\ldots]$ the desire to find a model[...], the struggle to find voice and authority [...]" (xx). Critic Emily Toth concurs when she insists that "being regional does not preclude the universal because "our most universalmost human —experiences happen at home"(9), and calls for "redefinition-not only of regionalism but of what constitutes significant literature and useful literary criticism" (11). Significantly, many of these critics' views and objectives conceivably parallel those of the women writers they analyze, particularly in terms of opening a space for themselvespersonally, socially, and professionally_and exercising voice.

Key regionalist authors, such as Kate Chopin, Sarah Orne Jewett, and Mary Wilkins Freeman, are exemplary evidence of the above. Their stories suggest that these writers took sagacious advantage of the opportunities proferred by the regionalist boon to examine women's space and place in their respective regions, to pass judgment on the same, and to foment revisionist agendas. Understandably, the patriarchal response was less than enthusiastic or supportive. As Joyce Warren has demonstrated, the mere fact of women writing constituted a threat to male literary hegemony, as manifested by an 1853 article in the United States Review which exhorted men to respond:

Where is American genius? Where are the original, the brilliant, the noble works, in whose publication we might take a lasting and national pride, from whose perusal we might derive delight, instruction, and elevation?

Where are the men to write them? [....]

American authors, be men and heroes! Make sacrifices, ... but publish books ... for

the hope of the future and the honor of America. Do not leave its literature in the hands of a few industrious females (1).

In examining the systematic exclusion of women writers from the literary canon, Warren, like Jane Tompkins, concludes that the issue of literary reputation is never simply one 
of literary quality, but rather responds to larger questions: 'The question 'Is it good?' is inextricably bound up with other questions: 'Good for whom?' 'When?' and 'Why?' “(2). She suggests that another major reason women's writing of the mid- and late-nineteenth century was perceived as threatening as as inferior was its divergence from the ideological foundations of U.S. literary canon. According to Warren, the fundamental assumption of American life is the belief in individualism; however, the individual is always male and white:

[...] the myth of American individualism [...is] the basis of American thought. [....]

Reflecting this assumption of individualism, canonized American literature- that is, the literature that has come to form what has been regarded as the American tradition—has, for the most part, focused on the individual. And since nineteenth-century American individualism applied only to the white male, the individual that forms the center of American literature has been universalized as white and male (3).

Warren contends that canonical shunning of the women authors of the time responds mostly, although not exclusively, to the fact that their writing "implicitly or explicitly [...] rejects this construction of American life: the assumption that the white male individual occupies center stage" (3). It does so by tending to focus on those supposedly "supporting players" who were traditionally marginalized by gender, race, and/or ethnicity, or even more insidiously, by privileging community over the individual.

Regionalist literature-especially that labelled "local color"-epitomizes both of these subversive tendencies, although it does so in ways which permit radically opposed interpretations of the visions it proffers. Because much regionalist writing, as discussed above, focuses not only on a reduced geographical area, but even more particularly on the reduced sphere of the women within it, it can also be placed within a subcategory of nineteenth literature known as "domestic" or "sentimental." Even though this fiction is generally posited as a movement preceding, and even contrasting with, realism because of its frequently melodramatic perpetuation of stereotypes of femininity, its presence is not insignificant in regionalist literature. A. D. Wood asserts that women local colorists actually "impoverished" the two most powerful resources of the sentimentalists - "their homes and their feminine roles, both of which were instruments and symbols of their beneficent but irresistible power over society at large and their men-fold in particular" (20). She affirms that, by so doing, "the Local Colorists present not a fundamental alteration, but rather a violent dislocation of the sentimental vision. They actually valued, as the sentimentalists ostensibly did, the conventional feminine virtues, but they have lost faith in their potency" (16). For example, in keeping with Gilbert's and Gubar's premise of enclosed spaces being representative of female wombs, Woods sees the home as a symbol of female space. However, she sees female local color authors as depicting it as barren, even damaging, as in Freeman's "Brakes and White Violets", where an aging Marm Lawson identifies with her home in destructive, decaying ways, or Freeman's "Sister Liddy", where the almshouse and its aged female occupants present a "spectrum of obsolete and frustrated womanhood" (Wood 25). Constance Woolson's short story "In the Cotton Country" deals with a "Yankee" woman's relentless appropriation of a southern woman's "home" in her former overseer's house, which is painful and detrimental to both women, and Mary Murfree's protagonist in "Drifting Down Lost Creek", Cynthia, is forced to make a choice "between two almost equally barren worlds", the urban valley society 
"based on principles inimical to her most essential feminine identity" and the rural world "which is itself harmonious with her feminine nature but which is fast losing the men she needs to bring that nature to flower" (Wood 19). From Woods' perspective, the local spaces and places of regionalist writing are synonymous with limitation, degeneration, and diminishment.

In contrast, Elaine Sargent Apthorp perceives a more positive relationship between the so-called sentimentalists and regionalist writers. In her view, "out of the cult of domesticity, which identifies 'the pure woman' as the moral glue of American society, grew the belief that, by exercising their intuitive and nurturing skills and teaching others to do likewise, women could achieve personal growth and social reform", and women writers could set this healing process in motion by appeals to sentiment-by which they meant the heart, the emotions, the sympathy, of the individual" (5). The key difference she finds is that the sentimentalists employed the discourse of religion, while the regionalists, particularly Freeman and Jewett, appealed to "a similar, if more secular, conviction that the points of commonality between human beings are more fundamental than their differences, and that it is sympathetic engagement, empathic imagination, which makes us real to one another" (7). Apthorp asserts that the women Local Colorists of Jewett's and Freeman's school demonstrate, "both in theme and in technique, a celebration of subjective perception, and continuity between the artist's philosophy and the posture she takes towards her material" (11). For example, in spite of Freeman's own significantly different life experiences, in "A Mistaken Charity", she uses her "inclination to see likeness between the Other and one self, and to resolve differences [...] by discovering fundamental similarities", as well as dramatic interaction and realistic dialogue, to establish that "the coarse Shattucks are able to experience emotional pain and imaginative pleasure" (15), and thus she encourages a sympathetic response from her readers. Unlike Woods, and aligned with her perception of the local color writers themselves, Apthorp sees the regionalists as relocating rather than losing their faith in feminine virtues and their spatial representations of them.

In like fashion, Millicent Bell looks beyond the often bleak landscapes of regionalist situations to what she describes as its "more authentic" center of femaleness: "Female regionalism celebrates an older source of life-vigor which has been forgotten or exhausted by modern society [...,] the immemorial linkage with all life which female wisdom preserves" (473). Although she acknowledges that the regionalist emphasis on differentiated language as an "essential defining feature" tends to highlight dialect as "the language of marginalization" and the fragmentary, sketch-like form as "attempting to make 'story' of marginality", she also sees them as deliberately proclaiming "an alternative way of seeing life" (474). In that sense, she sees regionalist writing as self-consciously subverting hegemonic patterns, both literary and social. Bell asserts that "[c]onspicuous in the works of [such writers as Harriet Beecher Stowe, Elizabeth Stuart Phelps, Rose Terry Cooks, and Mary Wilkins Freeman] is a realist fidelity to the conditions of humble life in village and rural environments, the valuation of feminine closeness to nature and independence along with the discovery of female solidarity" (477). She emphasizes the mythic nature underlying the local surface, especially in female arts and outlooks. For example, she calls Jewett's "The White Heron" a "feminist rewriting of the [Cinderella] myth" and perceives The Country of the Pointed Firs as a mythic utopia based on "the redemptive promise of womanly strength" (477). Bell's vision of regionalist writing is a 
benevolent one of the conditions "which cause women to seek an expression of their needs and offerings in the analogous viewpoint of subcultures distant from the centers of power, in peripheries, ethnic or geographic, which share both the weakness of the female situation and its sense of latent strengths, its special values" (469).

Bell is not alone in ascribing much larger importance to the seemingly insignificant locales of regionalist writing. Unlike Warren, Alice Hall Petry sees the values and qualities embodied in local-color writing as "the very values which all Americans-indeed, which all humans - regard as not simply good, but vital for human existence" (111). In "Universal and Particular: The Local-Color Phenomenon Reconsidered", Petry, perhaps somewhat ingenuously, identifies those positive values as honor, heroism, stoicism, adaptability, responsibility, and religious faith, and suggests that there is a strong element of didacticism at work in local-color writings. She also identifies certain narrative strategies employed by local-colorist writers in fomenting these values. The first of these is the "interloper" motif, where an outsider (who can be the narrator, a character, or even a contrasting place) enters an "alien" locale-which may be geographical, cultural, temporal, or a combination-and provides an opportunity to explain, defend, juxtapose, or otherwise engage the reader in consideration of the values upheld there, as the railroaders in Chopin's "At the "Cadian Ball." A common variation of this is "reverse interloping", where the "native" goes to another place (often from a rural to an urban setting), as in Murfree's "Drifting Down Lost Creek." Another frequent regionalist technique, according to Petry, is the universalization-explicit or otherwise - of a particular feature, whether through stressing some aspect of human nature as universal or through universalizing time by avoiding specific dates, places, or other textual clues, such as references to political events, which would particularize it. Petry suggests that regionalists also "universalize" by dealing with perennial human issues, such as the role of women or how to cope with death, which detract from locational specificity. Somewhat paradoxically, Petry even asserts that regionalists use a technique of indeterminate settings to de-particularize geographical location and foment "a quality of placelessness" (124) to infuse their writing with larger significance.

In a sense, Petry's attempts to project regionalism into more expansive realms parallel the efforts of other critics to "de-stigmatize" regionalism as a "feminine" mode of literature. In both instances, these critics, like the authors themselves, are challenging derogatory traditional perceptions. In the "Introduction" to Breaking Boundaries: New Perspectives on Women's Regional Writing, Sherrie Inness and Diana Royer declare that "[i]nstead of understanding regionalism as a literary genre associated narrowly with women writers from the late $1800 \mathrm{~s}$ and early 1900s, we view regionalism as always being a literary influence on U.S. women writers" (2). Reversing the traditional viewpoint permits them to perceive how "regional writing has been a way for women to write about their unique experiences and to critique hegemonic concepts, [...., a legacy of subversion, employing the conventions of the genre to put forth, whether covertly or not, social criticism and correctives" (2-3). They suggest that this is partly true due to the fact that originally the huge market offered a good opportunity for aspiring readers to get published. More importantly, the writers had "a lucrative source for writing right in their own backyards" (4); quoting Richard Brodhead, they reaffirm that regionalism "enfranchised a new set of social knowledges as a source of literary expertise" which "made of social marginality itself a positive authorial advantage" (4). This supports 
their position that women regionalists conscientiously appropriated the conventions of the genre for their own purposes-whether seeing region as community, kinship, or place. Inness and Royer clearly share a perception so articulately stated by Cecilia Tichi that female practitioners of regionalism use(d) it "as a space within which to explore 'the territory of women's lives,' 'to map the geography of their gender'” (qtd. in Fetterley "Theorizing" 52). Donna Campbell claims such statements respond to feminist critical efforts to reinterpret "the form's limitations in a more positive light" and cites Elizabeth Ammons' effort to transform "the inherent formal limitations of the sketch" into "a virtue rather than a flaw" through insistence that its very "lack of pretension to impressive scope" makes it "appealing" (22). Campbell sees a parallel between women regionalist writers and their feminist critics in the sense that both strive to turn adversity into virtue.

However, hovering around the seemingly inevitable comments about the worth and significance of regionalist literature, especially that of women authors, is a persistent association (frequently negative) of this subgenre with gender. Even those critics who celebrate women regionalists as preservers in the best sense of the word come dangerously close to falling into biological essentialism at best, patriarchal representations of "feminine virtue" at worst. . For example, in The Feminization of American Culture, Ann Douglas, like Apthorp, discusses the manner in which a coalition between women and religion "feminized" U.S. culture by fomenting "feminine" ideals of love, compassion, and charity. Campbell herself affirms that the positive values in women's local color fiction-patience, loyalty, responsibility, and compassion — are presented as feminine in these writings. She claims these values "presuppose the moral capacity to distinguish and choose right over wrong" and "the willingness to apply this knowledge even against one's own interests" and praises this as "necessary self-sacrifice" at the same time that she insists local colorists' attention to detail is "inseparable from their fictional purposes, indicating as it does the necessity for integrating the whole of life, however seemingly trivial or distasteful, into a coherent moral vision" (23). Her analysis accordingly concentrates on the ways in which the female characters in women regionalists' writing subordinate their own needs to those of the community in an effort to maintain social harmony and order. Valuations such as these, even when intended to be affirmative of women's roles in regionalist writing, are too often problematic because they fail to surpass cultural stereotypes of women as defined in terms of their relationships to others: nurturing, self-sacrificing, passive, self-effacing. In other words, these women continue to be represented as types rather than as authentic individuals.

Nevertheless, this same emphasis on community, when approached from a feminist perspective of cultural subjectivity, unexpectedly reopens discursive space for a decidedly different possibility: the appropriation of community for the purposes of personal agenda. Critics agree that a major theme, perhaps even the crux, of regionalist writing is loss, essentially in terms of a communal way of life, but whether that loss is viewed in terms of affectionate nostalgia for the simpler past, a desperate clinging to an idealized past, or a solid affirmation of traditional values and attitudes varies according to the agendas of both the writers and their readers. Lee Clark Mitchell has posited that the essence of local color fiction was "its preservation of self within a matrix of absence and loss" (Campbell 9), an observation which encompasses the classic dualities of regionalism, especially women regionalist writing: preservation vs. loss, self vs. community, absence vs. presence. Are these authors and their 
female protagonists apostles of loss or heroic saviours of tradition? Are they substituting a communal identity for a personal one, or are they subversively appropriating regionalism for their own ends? Are they solidifying their representation as "other", or are they reclaiming agency by criticizing and coping on their own terms? Traditional criticism of women regionalists, constructed upon patriarchal premises of gendered roles and values (literary and social), postulates a rather pathetic picture of them as timid tellers of "teacup tragedies", as Frank Norris once labeled them. But revisionist criticism tends to see beyond the placid surface of women regionalists' writing to an active revolution teeming within, one which reappropriates the physical space of the community and the rhetorical space of regionalist conventions to re-create a sense of community which challenges hegemonic constructions of place and self.

\section{Bibliography}

Ammons, Elizabeth. 1991. "Gender and Fiction." The Columbia History of the American Novel. Ed. Emory Elliott. New York: Columbia UP. 267-84.

Apthorp, Elaine Sargent. 1990. "Sentiment, Naturalism, and the Female Regionalist.” Legacy 7: 3-21.

Bell, Michael Davitt. 1993. The Problem of American Realism: Studies in the Cultural History of a Literary Idea. Chicago: U Chicago P.

Bell, Millicent. 1986. "Female Regional Writing: An American Tradition.” Revue Française de'études Américaines: 469-80.

Campbell, Donna M. 1997. Resisting Regionalism: Gender and Naturalism in American Fiction, 1885-1915. Athens: Ohio UP.

Cott, Nancy F. 1977. The Bonds of Womanhood: “Woman's Sphere” in New England, 17801835. New Haven: Yale UP.

Douglas, Ann. 1977. The Feminization of American Culture. NY: Knopf.

Fetterley, Judith. 1997. “Theorizing Regionalism.” Breaking Boundaries: New Perspectives on Women's Regional Writing. Eds. Sherrie A. Inness and Diana Royer. Iowa City: U Iowa P: 38-53.

Fetterley, Judith and Marjorie Pryse (Eds.) 1992. American Women Regionalists. New York: Norton,

Inness, Sherry and Diana Royer (Eds.). 1997. Breaking Boundaries: New Perspecitves on Women's Regional Writing. Iowa City: U Iowa P. 
Meyers, Kari. 2001. "The Politics of Place: Regionalism and Local Color Fiction in Nineteenth-Century U.S. Literature.” Revista de Filología y Lingüística. XXVII (2).

Petry, Alice Hall. 1979. "Universal and Particular: The Local-Color Phenomenon Reconsidered". American Literary Realism 1870-1910. XII: 111-26.

Pryse, Marjorie. 1993. "Distilling Essences: Regionalism and 'Women's Culture.'” American Literary Realism 1870-1910. XXV: 1-15.

Romines, Ann. 1992. The Home Plot: Women, Writing \& Domestic Ritual. Amherst: U Massachusetts P.

Tompkins, Jane. 1985. Sensational Designs: The Cultural Work of American Fiction 17901860. New York: Oxford.

Toth, Emily (Ed.). 1985. Regionalism and the Female Imagination: A Collection of Essays. New York: Human Sciences Press.

Warren, Joyce W. (Ed.) 1993. The (Other) American Traditions: Nineteenth-Century Women Writers. New Brunswick, NJ: Rutgers UP.

Wilson, Christopher P. 1991. "Introduction: The Late Nineteenth Century." The Columbia History of the American Novel. New York: Columbia UP: 157-9.

Wood, Ann D. 1972. "The Literature of Impoverishment: The Women Local Colorists in America 1865-1914". Women's Studies. 1: 3-45. 